\title{
Hubungan Kadar Troponin-I Dengan Selvester Qrs Score Pada Pasien Infark Miokardium Akut Di Rumah Sakit Umum Daerah Kota Mataram
}

\author{
*Baiq Nopria Dwi Cahyani ${ }^{1)}$, Romi Ermawan ${ }^{1)}$, Devi Rahmadhona ${ }^{1)}$ \\ ${ }^{1)}$ Fakultas Kedokteran, Universitas Mataram \\ *Correspondence author: Baiq Nopria Dwi Cahyani, baiqnopria@gmail.com, Mataram, Indonesia
}

\begin{abstract}
Abstrak
Infark miokardium akut merupakan salah satu manifestasi dari penurunan atau penghentian aliran darah menuju jantung sehingga menyebabkan terjadinya nekrosis pada otot jantung. Untuk mendiagnosis infark miokardium akut salah satunya menggunakan biomarker jantung. Biomarker jantung yang digunakan yaitu troponin-I yang merupakan lini pertama untuk mengevaluasi infark miokardium akut. Luas infark pada pasien infark miokardium akut dapat diperkirakan dengan Selvester QRS score yang merupakan metode tidak invasif. Penelitian ini bertujuan untuk mengetahui hubungan kadar troponin-I dengan Selvester QRS score pada pasien infark miokardium akut di Rumah Sakit Umum Daerah Kota Mataram. Penelitian ini merupakan studi cross sectional yang dilakukan di Rumah Sakit Umum Daerah Kota Mataram. Subjek penelitian adalah pasien infark miokardium akut di Rumah Sakit Umum Daerah Kota Mataram yang telah memenuhi kriteria inklusi dan ekslusi. Data sekunder diambil dari rekam medis pasien yaitu nama, usia, jenis kelamin, kadar troponin-I, dan hasil pemeriksaan elektrokardiogram (EKG). Setelah mendapatkan data dari EKG maka akan dihitung luas infark miokardium dengan menggunakan Selvester QRS score. Total subjek penelitian ini 52 pasien, yang terdiri dari $71.2 \%$ pasien laki-laki dan $28.8 \%$ pasien perempuan. Usia rata-rata pada penelitian ini yaitu 58.06 tahun. Berdasarkan hasil uji korelasi didapatkan tidak ada hubungan yang signifikan antara kadar troponin-I dengan Selvester QRS score $(\mathrm{p}=0.449)$. Penelitian ini juga menemukan bahwa tidak terdapat korelasi yang signifikan antara usia dengan Selvester QRS score $(\mathrm{p}=0.371)$ dan jenis kelamin dengan Selvester $Q R S$ score $(\mathrm{p}=0.171)$. Penelitian ini menemukan tidak terdapat hubungan yang signifikan antara kadar troponin-I dengan Selvester QRS score pada pasien infark miokardium akut di Rumah Sakit Umum Daerah Kota Mataram.
\end{abstract}

Kata Kunci: Kadar troponin-I; Selvester QRS score; infark miokardium akut.

\begin{abstract}
Acute myocardial infarction is one of the manifestations of decreased or stopping blood flow to the heart, causing necrosis of the heart muscle. To diagnose acute myocardial infarction, one of them uses cardiac biomarkers. The cardiac biomarker used is troponin-I, which is the first line to evaluate acute myocardial infarction. The infarct area in acute myocardial infarction patients can be estimated by using the Selvester QRS score, which is a noninvasive method. This study aims to see the relationship between troponin-I levels and Selvester QRS score in acute myocardial infarction patients at Rumah Sakit Umum Daerah Kota Mataram. This study was a cross sectional study conducted at Rumah Sakit Umum Daerah Kota Mataram. The research subjects were patients with acute myocardial infarction at Rumah Sakit Umum Daerah Kota Mataram which had met the inclusion and exclusion criteria. Secondary data were taken from the patient's medical record, namely name, age, gender, troponin-I levels, and the results of an electrocardiogram (ECG). Aftre obtaining data from the ECG, the area of myocardial infarction will be calculated using the QRS Selvester score. The total subjects of this study were 52 patients, consisting of $71.2 \%$ male and $28.8 \%$ female. The average age in this study was 58.06 years. Based on the results of the correlation test, it was found that there was no significant relationship between troponin-I levels and Selvester QRS score $(\mathrm{p}=0.449)$. This study also found that there was no significant correlation between age and Selvester QRS score $(\mathrm{p}=0.371)$ and gender with Selvester QRS score $(\mathrm{p}=0.171)$. This study found that there was no significant
\end{abstract}

Open Journal System (OJS): journal.thamrin.ac.id 
relationship between troponin-I levels and Selvester QRS score in patients with acute myocardial infarction at Rumah Sakit Umum Daerah Kota Mataram.

Keywords: troponin-I levels; Selvester QRS score; acute myocardial infarction.

\section{PENDAHULUAN}

American Heart Association pada tahun 2016 melaporkan bahwa 15,5 juta orang yang berusia $\geq 20$ tahun di Amerika Serikat menderita Penyakit Jantung Koroner. Prevalensi penyakit jantung di Indonesia pada tahun 2018 yaitu 1,5\% (Riskesdas, 2018). Menurut Riskesdas tahun 2013 terdapat 478.000 pasien di Indonesia yang terdiagnosa mengalami Penyakit Jantung Koroner. Prevalensi infark miokardium akut di dunia yaitu mendekati tiga juta orang dan merupakan salah satu penyebab terjadinya kematian di negara berekembang (Mechanic O.J., Grossman S.A., 2020).

Infark miokardium akut merupakan salah satu manifestasi dari penurunan atau penghentian aliran darah menuju jantung sehingga menyebabkan terjadinya nekrosis pada otot jantung (Ojha N., Dhamoon A.S., 2020; Bahall M., Seemungal T., \& Legall G., 2018). Untuk mendiagnosis infark miokardium akut bisa menggunakan manifestasi klinis, elektrokardiogram, dan biomarker jantung. Biomarker jantung yang digunakan untuk menegakkan diagnosis infark miokardium yaitu Creatine Kinase Myocardial Band, mioglobin, dan troponin. Troponin jantung merupakan tes yang dilakukan pada lini pertama untuk mengevaluasi infark miokardium akut (Saleh M., \& Ambrose J.A., 2018; Basit H., Huecker M.R., 2020; Patibandla S., Gupta K., Alsayouri K., 2020).

Luas infark merupakan prediktor utama untuk menentukan prognosis pada pasien pasca infark miokardium (Ho C., Cimon K., Weeks L., et al., 2016; Lee D.C., et al., 2020; Tiller C., et al., 2019). Gold standar untuk menentukan luas infark yaitu Cardiovascular Magnetic Resonance (CMR). Tetapi dalam praktik secara klinis elektrokardiogram merupakan alat diagnosis pada lini pertama untuk mengevaluasi pasien dengan dugaan penyakit jantung iskemik karena mempunyai beberapa kelebihan yaitu merupakan pemeriksaan non invasif, lebih aman, biaya lebih murah, dan ketersediannya hampir universal (Ho C., Cimon K., Weeks L., et al., 2016; Rosendahl L., 2010).

Luas infark miokardium akut dapat diperkirakan dengan menggunakan Selvester $Q R S$ score dari pemeriksaan elektrokardiogram. Selvester $Q R S$ score berfungsi menerjemahkan 
perubahan depolarisasi ventrikel yang diukur dengan elektrokardiogram (EKG) untuk mendapatkan informasi lokasi dan ukuran bekas luka miokardium. Selain itu Selvester QRS Score dapat memberikan prediksi mengenai prognostik (Parviz Y., Vijayan S., \& Lavi S., 2017). Oleh karena tingginya angka prevalensi infark miokardium akut yang terjadi di Indonesia, maka dibutuhkan diagnosis dini yang cepat untuk mencegah terjadinya komplikasi yang tidak diinginkan seperti terjadinya kematian. Prognosis pasien infark miokardium akut bisa ditentukan melalui luas infark miokardium salah satunya dengan menggunakan elektrokardiogram yang mempunyai beberapa kelebihan daripada alat yang lainnya. Sehingga saya tertarik mengambil penelitian mengenai "Hubungan Kadar Troponin-I dengan Selvester QRS score pada Pasien Infark Miokardium Akut di Rumah Sakit Umum Daerah Kota Mataram."

\section{METODE PENELITIAN}

Penelitian ini merupakan penelitian yang dilakukan dengan desain analitik observasional menggunakan metode pendekatan cross sectional untuk mengetahui hubungan kadar troponinI dengan Selvester QRS score pada pasien infark miokardium akut di Rumah Sakit Umum Daerah Kota Mataram. Penelitian ini dilakukan di Rumah Sakit Umum Daerah Kota Mataram dan data rekam medis pasien yang digunakan sejak Januari sampai November 2020. Sampel pada penelitian ini yaitu pasien yang terdiagnosis infark miokardium akut yang mempunyai hasil pemeriksaan troponin-I dan elektrokardiogram pada saat sedang terjadinya infark miokardium. Penelitian ini menggunakan teknik non-probability sampling, yaitu concecutive sampling.

Kriteria inklusi pada penelitian ini yaitu pasien yang terdiagnosis infark miokardium akut dan pasien yang memiliki hasil pemeriksaan troponin-I dan elektrokardiogram yang dilakukan saat sedang terjadinya infark miokardium akut. Adapun kriteria ekslusi yaitu catatan rekam medis yang tidak lengkap, hasil rekaman elektrokardiogram yang tidak bisa diinterpretasikan, dan pasien yang sebelumnya pernah terdiagnosis infark miokardium akut. Faktor-faktor perancu pada penelitian ini yaitu usia $>45$ tahun, jenis kelamin laki-laki, genetik, dislipidemia, merokok, hipertensi, diabetes mellitus, kurangnya aktivitas fisik, ketidak- 
optimalan terapi penyakit kardiovaskular, onset infark miokardium akut dan penanganan infark miokardium akut.

Penelitian ini menggunakan data sekunder yaitu rekam medis pasien untuk mengetahui hubungan kadar troponin-I dengan Selvester QRS score. Setelah didapatkan data penelitian, selanjutnya dilakukan pengolahan dan analisis data menggunakan uji normalitas dan uji korelasi Spearman untuk mengetahui hubungan dan kekuatan korelasi antar variabel.

\section{HASIL DAN PEMBAHASAN}

Jumlah subjek pada penelitian ini yaitu 52 sampel. Sebanyak 37 orang berjenis kelamin laki-laki (71.2\%) dan 15 orang berjenis kelamin perempuan $(28.8 \%)$. Rata-rata usia sampel pada penelitian ini yaitu 58.06 tahun. Kelompok usia terbagi menjadi beberapa kelompok, dimana kelompok usia terbanyak yaitu $>60$ tahun ada 23 orang. Sedangkan kelompok usia $<45$ tahun ada 8 orang dan kelompok usia 45-60 tahun ada 21 orang.

Dari 52 sampel penelitian didapatkan rata-rata kadar troponin-I yaitu $14106.87 \mathrm{ng} / \mathrm{L}$. Frekuensi kadar troponin-I dibagi menjadi dua kelas berdasarkan cutoff poin yang sudah ditentukan di Laboratorium Rumah Sakit Umum Daerah Kota Mataram yaitu $<9$ ng/L ada 4 orang dan $>9 \mathrm{ng} / \mathrm{L}$ ada 48 orang.

Rata-rata Selvester QRS score pada penelitian ini yaitu 8.44. Frekuensi Selvester QRS score dibagi menjadi tiga kelompok berdasarkan nilai dari skoring yaitu kategori rendah (0-1), sedang (2-4), dan berat (>5) (Loring Z., et al., 2011) . Berikut tabel frekuensinya:

Table 1.

\begin{tabular}{|c|c|}
\hline \multicolumn{2}{|c|}{ Frekuensi Selvester QRS Score } \\
\hline Selvester & QRS Score \\
\hline $0-1$ & 0 \\
\hline $2-4$ & 4 \\
\hline$>5$ & 48 \\
\hline
\end{tabular}

Selanjutnya dilakukan uji normalitas data dengan menggunakan uji KomlogorovSmirnov, setelah dilakukan uji normalitas didapatkan Sig $<0.05$ yang bermakna distribusi 
datanya tidak normal. Setelah itu dilakukan transformasi data dengan menggunakan transformasi square root (sqrt), hasilnya yaitu transformasi Selvester $Q R S$ score Sig $>0.05$ yang bermakna distribusi data normal tetapi pada kadar troponin-I Sig $<0.05$ yang bermakna tidak terdistribusi normal. Sehingga pada penelitian ini digunakn uji korelasi Spearman, hasilnya yaitu nilai $\mathrm{p}=0.499$ yang bermakna tidak terdapat hubungaan yang signifikan antara kadar troponin-I dengan Selvester QRS score.

Sebagian besar sampel pada penelitian ini berjenis kelamin laki-laki yaitu sebanyak 37 orang $(71.2 \%)$. Jenis kelamin laki-laki merupakan salah satu faktor risiko infark miokardium akut yang tidak dapat diubah (Ojha N., Dhamoon A.S., 2020; Kosuge M., et al, 2011; Ahmadi A.,et al., 2015). Insiden infark miokardium akut lebih tinggi pada jenis kelamin laki-laki, tetapi jika usia lebih dari 75 tahun insiden pada laki-laki dan perempuan sama (Lilly L.S., Lee C.T., \& Williams G.H., 2015).

Berdasarkan usia pada sampel penelitian ini, untuk yang berusia $<45$ tahun ada 8 orang, 45-60 tahun ada 21 orang dan usia $>60$ tahun ada 23 orang. Rata-rata usia pada sampel penelitian ini yaitu 58.06 tahun. Dari beberapa faktor risiko infark miokardium akut, salah satunya yaitu usia $>45$ tahun (Ojha N., Dhamoon A.S., 2020; Kosuge M., et al, 2011; Ahmadi A.,et al., 2015). Rata-rata usia infark miokardium untuk laki-laki yaitu 65.5 tahun dan perempuan 72 tahun (Ojha N., Dhamoon A.S., 2020).

Kadar rata-rata troponin-I pada penelitian ini yaitu 14106.87 ng/L. Frekuensi kadar troponin-I yang dibagi berdasarkan cutoff poin yang telah ditentukan di Rumah Sakit Umum Daerah Kota Mataram yaitu $<9 \mathrm{ng} / \mathrm{L}$ ada 4 orang dan $>9 \mathrm{ng} / \mathrm{L}$ ada 48 orang. Troponin-I merupakan subunit yang paling sensitif untuk mendiagnosis infark miokardium. Nilai troponin yang menunjukkan kerusakan otot secara patologis jika lebih besar dari persentil ke-99 terhadap kisaran normal yaitu sekitar 3 deviasi standar dari rata-rata (Goyal A, Zeltser R., 2020).

Setelah dilakukan korelasi antara kadar troponin-I dengan Selvester QRS score didapatkan nilai $\mathrm{p}=0.449$, sehingga disimpulkan $\mathrm{p}>0.05$ artinya tidak terdapat korelasi yang signifikan antara variabel independen yaitu kadar troponin-I dengan variabel dependen yaitu Selvester QRS score. Sehingga dapat disimpulkan bahwa tidak terdapat hubungan antara kadar troponin-I dengan Selvester QRS score pada pasien infark miokardium akut di Rumah Sakit Umum Daerah Kota Mataram. 
Penelitian ini sesuai dengan penelitian yang dilakukan oleh Lingga P.M., et al.,2016., tentang hubungan antara kadar troponin-T dengan luas infark miokard yang diukur dengan menggunakan metode skoring QRS Selvester pada pasien infark miokard akut hasilnya tidak terdapat hubungan yang signifikan antara kadar troponin T dan luas infark pada pasien IMA di RS Khusus Jantung YJI Cabang Utama Sumatera Barat periode Juli 2013 - Juni 2014. Hanya saja pada kadar troponin $\mathrm{T}$ yang meningkat ditemukan peningkatan jumlah penderita dengan luas infark yang meningkat pula. Tidak signifikannya hasil penelitian mungkin dikarenakan adanya variasi dan rentang waktu peningkatan troponin $\mathrm{T}$ saat terjadi kerusakan miokardium. Sampel pada penelitian ini sebanyak 81 orang dengan teknik total sampling, dimana 37 orang yang memenuhi kriteria inklusi dan 44 sampel diekslusi. Pada penelitian tersebut menggunakan kriteria ekslusi yaitu pasien IMA dengan onset $>12$ jam, gangguan konduksi (LBBB, RBBB, LAFB), LVH, riwayat infark miokardium sebelumnya, blok AV total dan data tidak lengkap. Didukung lagi dengan penelitian mengenai Selvester QRS score dan perubahan skor QRS untuk memprediksi prognosis pada pasien dengan peningkatan segmen ST akut infark miokardium setelah intervensi koroner perkutan (PCI) yang dilakukan oleh Liu Q., et al., 2020., menggunakan sampel 426 pasien. Hasil pada penelitian ini yaitu skor QRS dasar dan skor $\Delta$ QRS berkorelasi positif dengan LVMI ( $\mathrm{r}=0.146$ dan 0.158 , masing-masing) LAVI ( $\mathrm{r}=0.218$ dan 0.152 , masing-masing) dan fraksi ejeksi ventrikel kiri (LVEF) ( $\mathrm{r}=0.225$ dan 0.275 , masingmasing). Selain itu juga terdapat korelasi negatif yang signifikan antara skor QRS awal dan skor $\triangle \mathrm{QRS}$ dan LVEF ( $\mathrm{r}=-0.263$ dan -0.236, masing-masing). Namun skor QRS dasar bukan skor $\triangle \mathrm{QRS}$ berkorelasi positif dengan kadar troponin-I $(\mathrm{r}=0.206)$, kadar CKMB $(\mathrm{r}=0.176)$ dan NT$\operatorname{proBNP}(\mathrm{r}=0.212)$.

Hasil penelitian yang berbeda ditemukan pada penelitian yang dilakukan oleh Tiller C., et al., 2019 mengenai complete Selvester QRS score dengan simplified Selvester QRS score untuk menilai keparahan infark pada STEMI, pada penelitian ini menggunakan sampel 201 pasien STEMI. Pasien dengan complete $Q R S$ scores $>12$ poin $(\mathrm{p}=0.001$ ) yang menunjukkan denyut jantung lebih tinggi $(\mathrm{p}=0.041)$, tingkat hs-cTnT lebih tinggi $(\mathrm{p}<0.001)$, luas infark lebih besar pada saat akut $(\mathrm{p}=0.004)$ dan kronis $(\mathrm{p}=0.008)$ dan MVO lebih tinggi $(\mathrm{p}=0.020)$. Sedangkan pasien dengan complete $Q R S$ score $>4$ poin $(\mathrm{p}=0.004)$ menunjukkan indeks massa tubuh yang lebih tinggi $(\mathrm{p}=0.044)$, tingkat lokalisasi infark anterior lebih tinggi $(\mathrm{p}<0.001)$, tingkat hs-cTnT lebih tinggi $(\mathrm{p}<0.001)$, luas infark lebih besar saat akut $(\mathrm{p}=0.001)$ dan kronis 
$(\mathrm{p}=0.003)$ dan MVO lebih tinggi $(\mathrm{p}=0.013)$. Dalam beberapa tahun terakhir hs-cTnT diusulkan sebagai biomarker pilihan untuk menilai kerusakan miokard pada STEMI akut.

Berbeda dengan penelitian yang dilakukan oleh Lingga P.M., et al.,2016., tentang hubungan antara kadar troponin- $\mathrm{T}$ dengan luas infark miokard yang diukur dengan menggunakan metode skoring QRS Selvester pada pasien infark miokard akut hasilnya tidak terdapat hubungan yang signifikan antara kadar troponin $\mathrm{T}$ dan luas infark pada pasien IMA di RS Khusus Jantung YJI Cabang Utama Sumatera Barat periode Juli 2013 - Juni 2014. Hanya saja pada kadar troponin $\mathrm{T}$ yang meningkat ditemukan peningkatan jumlah penderita dengan luas infark yang meningkat pula. Tidak signifikannya hasil penelitian mungkin dikarenakan adanya variasi dan rentang waktu peningkatan troponin $\mathrm{T}$ saat terjadi kerusakan miokardium. Sampel pada penelitian ini sebanyak 81 orang dengan teknik total sampling, dimana 37 orang yang memenuhi kriteria inklusi dan 44 sampel diekslusi. Pada penelitian tersebut menggunakan kriteria ekslusi yaitu pasien IMA dengan onset $>12 \mathrm{jam}$, gangguan konduksi (LBBB, RBBB, LAFB), LVH, riwayat infark miokardium sebelumnya, blok AV total dan data tidak lengkap. Didukung lagi dengan penelitian mengenai Selvester QRS score dan perubahan skor QRS untuk memprediksi prognosis pada pasien dengan peningkatan segmen ST akut infark miokardium setelah intervensi koroner perkutan (PCI) yang dilakukan oleh Liu Q., et al., 2020., menggunakan sampel 426 pasien. Hasil pada penelitian ini yaitu skor QRS dasar dan skor $\triangle \mathrm{QRS}$ berkorelasi positif dengan LVMI ( $\mathrm{r}=0.146$ dan 0.158 , masing-masing) LAVI ( $\mathrm{r}=0.218$ dan 0.152, masing-masing) dan fraksi ejeksi ventrikel kiri (LVEF) ( $\mathrm{r}=0.225$ dan 0.275, masingmasing). Selain itu juga terdapat korelasi negatif yang signifikan antara skor QRS awal dan skor $\triangle \mathrm{QRS}$ dan LVEF ( $\mathrm{r}=-0.263$ dan -0.236 , masing-masing). Namun skor QRS dasar bukan skor $\triangle$ QRS berkorelasi positif dengan kadar troponin-I $(\mathrm{r}=0.206)$, kadar CKMB $(\mathrm{r}=0.176)$ dan NTproBNP $(\mathrm{r}=0.212)$.

Penelitian ini juga didukung oleh penelitian yang dilakukan oleh Sundari A., 2015 dalam penelitiannya yang berjudul Hubungan Luas Infark Miokard (Berdasarkan Skor Selvester) dengan Kadar Troponin I pada Pasien Sindrom Koroner Akut di RSUD dr. Soebandi Jember hasilnya yaitu dengan menggunakan uji regresi logistik ditemukan bahwa luas infark mempunyai pengaruh yang signifikan pada kadar troponin-I positif $(p=0.064)$ artinya terdapat hubungan antara luas infark miokard dengan kadar troponin-I positif pada pasien sindrom koroner akut. Pada penelitian ini nilai $\mathrm{OR}=1.161$ yang bermakna setiap kenaikan luas infark 
sebesar 1\% maka akan meningkatkan kadar troponin-I positif 1.161 kali lebih besar. Hasil penelitian ini menunjukkan bahwa semakin tinggi prosentase skor selvester akan semakin positif kadar troponin I. Hal ini juga didukung oleh penelitian Jamil M., 2017, dalam penelitiannya hasilnya yaitu terdapat hubungan antara troponin dan diagnosis ST Elevasi Sindrom Koroner Akut (STESKA) dan Non ST Elevasi Sindrom Koroner Akut (NSTESKA) berhubungan signifikan dimana nilai $\mathrm{p}=0.001$.

Berdasarkan penelitian yang telah dilakukan hasilnya tidak terdapat hubungan antara variabel independen yaitu troponin-I dengan variabel dependen yaitu Selvester QRS score. Dimana penelitian ini didukung oleh penelitian yang dilakukan oleh Lingga., et al., 2016 yang dalam penelitiannya dijelaskan bahwa tidak terdapat hubungan yang signifikan antara troponin $\mathrm{T}$ dan luas infark pada pasien IMA di RS Khusus Jantung dimana pada penelitian ini disebutkan bahwa hasil dari penelitian ini dipengaruhi oleh adanya variasi dan rentang waktu peningkatan troponin $\mathrm{T}$ saat terjadi kerusakan miokardium. Selain itu juga penelitian ini didukung oleh penelitian yang dilakukan oleh Liu Q., et al., 2020 dalam penelitiannya disebutkan bahwa skor QRS dasar berkorelasi positif dengan kadar troponin-I ( $\mathrm{r}=0.206)$. Hal ini sesuai dengan penelitian yang dilakukan dimana terdapat korelasi positif dengan nilai korelasi rendah. Hasil dari penelitian ini dipengaruhi oleh jumlah sampel yang dilakukan oleh peneliti dimana sampel untuk penelitian ini 52. Jika dilihat dari penelitian yang dilakukan Tiller C., et al., 2019 jumlah sampelnya 201 pasien dan hasil penelitiannya terdapat hubungan yang signifikan.

Terdapat beberapa kekurangan pada penelitian ini, diantaranya adalah kurangnya sampel. Hal ini disebabkan karena pada penelitian ini hanya menggunakan pasien dengan diagnosis ST Elevasi yang dilihat pada elektrokardiogram (EKG). Hal lain yang mempengaruhi yaitu kemungkinan karena adanya kelemahan pada saat membaca hasil elektrokardiogram (EKG) yang disebabkan karena hasil EKG (elektrokardiogram) yang sudah lama. Selain itu juga dapat disebabkan oleh faktor-faktor perancu dalam penelitian ini yaitu usia, jenis kelamin, genetik, dislipidemia, merokok, hipertensi, diabetes mellitus, kurangnya aktivitas fisik, ketidakoptimalan terapi penyakit kardiovaskular, onset infark miokardium akut dan penanganan infark miokardium akut. Hal-hal tersebut tidak dimasukkan sebagai kriteria ekslusi pada penelitian ini, sehingga membuat penelitian ini hasilnya tidak signifikan. Selain itu hasil penelitian ini juga dipengaruhi oleh onset dari pengambilan troponin, dalam pengambilan sampel pada penelitian ini tidak memperhatikan onset dari pengambilan troponin. Dimana kadar troponin akan Open Journal System (OJS): journal.thamrin.ac.id 
meningkat sampai puncak pada 12-48 jam dan kadar troponin akan turun sampai kembali normal 4 sampai 10 hari. Kemudian juga karena adanya beberapa hasil elektrokardiogram (EKG) yang tidak bisa diinterpretasikan sehingga tidak dapat dimasukkan kedalam kriteria inklusi. Seringkali ditemukan artefak pada gelombang Q,R, dan S sehingga membuat proses penilaian dengan menggunakan Selvester $Q R S$ score tidak dapat dilakukan dengan maksimal.

\section{SIMPULAN}

Berdasarkan penelitian yang dilakukan di Rumah Sakit Umum Daerah Kota Mataram, didapatkan jumlah sampel yang masuk kedalam kriteria ekslusi dan inklusi yaitu ada 52. Hasil analisis data pada penelitian ini dengan menggunakan korelasi yang dipilih yaitu uji spearman nilai $\mathrm{p}$ yang didapatkan yaitu $\mathrm{p}=0.499$ yang bermakna tidak terdapat hubungan yang signifikan antara kadar troponin-I dengan Selvester QRS score sesuai dengan data rekam medis pasien dengan diagnosis infark miokardium akut di Rumah Sakit Umum Daerah Kota Mataram periode Januari 2019 sampai dengan November 2020.

\section{REFERENSI}

American Heart Association (AHA). (2016). Heart Disease and Stroke Statistics.

Ahmadi, A., Soori, H., Mehrabi, Y., Etemad, K., \& Khaledifar, A. (2015). Epidemiological pattern of myocardial infarction and modelling risk factors relevant to in-hospital mortality: The first results from the Iranian Myocardial Infarction Registry. Kardiologia Polska, 73(6), 451-457. https://doi.org/10.5603/KP.a2014.0230

Bahall, M., Seemungal, T., \& Legall, G. (2018). Risk factors for first-time acute myocardial infarction patients in Trinidad. BMC Public Health, 18(1), 1-8. https://doi.org/10.1186/s12889-018-5080-y

Basit H, Huecker MR. Myocardial Infarction Serum Markers. (2019). In: StatPearls [Internet]. Treasure Island (FL): StatPearls Publishing; 2020 Jan-. Available from: https://www.ncbi.nlm.nih.gov/books/NBK532966/ 
Goyal A, Zeltser R. Unstable Angina. (2020). In: StatPearls [Internet]. Treasure Island (FL): StatPearls Publishing; 2020 Jan-. Available from: https://www.ncbi.nlm.nih.gov/books/NBK442000/

Ho C, Cimon K, Weeks L, et al. (2016). Point-of-Care Troponin Testing in Patients With Symptoms Suggestive of Acute Coronary Syndrome: A Health Technology Assessment [Internet]. Ottawa (ON): Canadian Agency for Drugs and Technologies in Health; (CADTH Optimal Use Report, No. 5.1b.) 1, Introduction. Available from: https://www.ncbi.nlm.nih.gov/books/NBK362842/

Kosuge, M., Ebina, T., Hibi, K., Iwahashi, N., Tsukahara, K., Endo, M., Maejima, N., Hashiba, K., Suzuki, H., Umemura, S., \& Kimura, K. (2011). High QRS Score on Admission Strongly Predicts Impaired Myocardial Reperfusion in Patients With a First Anterior Acute Myocardial Infarction. Circ. J. 75: 626-632, http://www.j-circ.or.jp.

Lee, D. C., Albert, C. M., Narula, D., Kadish, A. H., Panicker, G. K., Wu, E., ... Goldberger, J. J. (n.d.). (2020). Estimating Myocardial Infarction Size With a Simple Electrocardiographic Marker Score. https://doi.org/10.1161/JAHA.119.014205

Lilly, L. S., Lee, C. T., \& Williams, G. H. (2015). Pathophysiology of Heart Disease 6th Edition. In Pathophysiology of Heart Disease.

Lingga Primananda, M., Syafri, M., \& Meinapuri, M. (2016). Hubungan antara Kadar Troponin T dengan Luas Infark Miokard yang Diukur dengan Menggunakan Metode Skoring QRS Selvester pada Pasien Infark Miokard Akut. Jurnal Kesehatan Andalas, 5(3), 486-490. https://doi.org/10.25077/jka.v5i3.562

Liu, Q., Zhang, Y., Zhang, P., Zhang, J., Cao, X., He, S., \& Yang, D. (2020). Both baseline Selvester QRS score and change in QRS score predict prognosis in patients with acute ST-segment elevation myocardial infarction after percutaneous coronary intervention. Coronary Artery Disease, (January 2014), 403-410. https://doi.org/10.1097/MCA.0000000000000869

Loring, Z., Chelliah, S., Selvester, R. H., Wagner, G., \& Strauss, D. G. (2011). A detailed guide for quantification of myocardial scar with the Selvester QRS score in the presence of electrocardiogram confounders. Journal of Electrocardiology, 44(5), 544-554. https://doi.org/10.1016/j.jelectrocard.2011.06.008 
Mechanic OJ, Grossman SA. Acute Myocardial Infarction. (2020). In: StatPearls [Internet]. Tresure Island(FL): Statpearls Publishing:2020 Jan-.

Ojha N, Dhamoon AS. Myocardial Infarction. (2020). In: StatPearls

Ojha N, Dhamoon AS. Myocardial Infarction. (2020). In: StatPearls [Internet]. Treasure Island (FL): StatPearls Publishing; 2020 Jan-. Available from: https://www.ncbi.nlm.nih.gov/books/NBK537076/

Patibandla S, Gupta K, Alsayouri K. Cardiac Enzymes. (2020). In: StatPearls [Internet]. Treasure Island (FL): StatPearls Publishing; 2020 Jan-. Available from: https://www.ncbi.nlm.nih.gov/books/NBK545216/

Parviz, Y., Vijayan, S., \& Lavi, S. (2017). A review of strategies for infarct size reduction during acute myocardial infarction. Cardiovascular Revascularization Medicine, 18(5), 374383. https://doi.org/10.1016/j.carrev.2017.02.004

Riset Kesehatan Dasar (Riskesdas). (2018). Badan Penelitian dan Pengembangan Kesehatan Kementerian RI tahun 2018. (2018). www.depkes.go.id

Rosendahl, L. (2010). Infarct Size and Myocardial Function. (1169)

Saleh, M., \& Ambrose, J. A. (2018). Understanding myocardial infarction [version 1; referees: 2 approved]. $\quad$ F1000Research, $\quad 7(0), \quad 1-8$. https://doi.org/10.12688/f1000research.15096.1

Stark M, Kerndt CC, Sharma S. Troponin. (2020). In: StatPearls [Internet]. Treasure Island (FL): StatPearls Publishing; 2020 Jan-. Available from: https://www.ncbi.nlm.nih.gov/books/NBK507805/?report=classic

Sundari, A. (2015). Hubungan luas infark miokard (berdasar skor selvester) dengan kadar troponin i pada pasien sindrom koroner akut (ska) di rsd dr. soebandi jember. The Indonesian Journal of Health Science, 5(2), 137-149.

Tiller, C., Reindl, M., Holzknecht, M., Klapfer, M., Beck, A., Henninger, B., ... Metzler, B. (2019). Biomarker assessment for early infarct size estimation in ST-elevation myocardial infarction. European Journal of Internal Medicine, 64(December 2018), 57-62. https://doi.org/10.1016/j.ejim.2019.03.001

Tiller, C., Reindl, M., Reinstadler, S. J., Holzknecht, M., Schreinlechner, M., Peherstorfer, A., ... Metzler, B. (2019). Complete versus simplified Selvester QRS score for infarct 
severity assessment in ST-elevation myocardial infarction. BMC Cardiovascular Disorders, 19(1), 1-7. https://doi.org/10.1186/s12872-019-1230-0 